\title{
Knowledge of Learning Disabilities among Pre-service and In-service Trainee Teachers in Malaysia
}

\author{
Supiah Saad, Siti Rafiah Abd Hamid, Khamsiah Ismail*
}

\begin{abstract}
Are mainstream teachers in Malaysia knowledgeable about types of students with special needs? Are there enough support services as well as facilities provided for these students' education? This study investigated the knowledge level of Malaysian in-service trainee teachers undergoing a distance learning Bachelor of Education program sponsored by the Malaysian Ministry of Education and pre-service trainee teachers enrolled in a regular bachelor of education program. The sample consisted of 296 students of bachelor degrees at two public universities, 39 males and 257 females; 147 inservice student teachers and 149 pre-service student teachers. The respondents completed a 36-item survey designed by the researchers, which had adequate psychometric properties. The results of the study revealed that student teachers had a rich level of knowledge on a few aspects of learning disabilities and a moderate level of knowledge in other aspects tested. In-service student teachers were found to be more knowledgeable than pre-service student teachers. Student teachers' level of knowledge was not related to their age and teaching experience. However their level of knowledge was somehow related to their status. Mass media were the main sources of information for both groups of trainee teachers. The implications of these findings for inclusive education and for future research in Malaysia are discussed.
\end{abstract}

Keywords: learning disabilities, special education, inclusive education, integration, media, knowledge, professional development.

\footnotetext{
* Kulliyyah of Education International Islamic University Malaysia
} 


\section{Introduction}

In the past, students who were labeled as 'handicapped' were excluded from the 'normal' schools, and placed in segregated educational settings. Human rights and social justice theories have influenced the development of an inclusive setting which then influenced the acceptance of students with disabilities in mainstream schooling. The Education for All (EFA) policy paved the way for students with disabilities between the ages of 5 and 21 to be educated whenever possible with students without disabilities. In Malaysia, inclusive education was promoted through a pilot project in 1995. Malaysia has recently become interested in the inclusion of students with special needs into mainstream settings. Under the transformation thrust (MOE, 2012), promoting inclusive education is one of the important push in which the placement of special needs students will be based on functional ability. All categories of students with disabilities will have a chance for inclusive education. Currently, about $1 \%$ of students with disabilities are in mainstream classrooms (Special education division, 2012). Nevertheless, like many other developing countries, students with sensory impairments or mild intellectual and physical impairments have been included in regular classrooms with minimum or no support. Students with learning disabilities are expected to have problems in academic performance due to dysfunctions in the brain (Hallahan \& Kauffman, 2000). As a result, teachers and school administration struggle to cope with these students' academic achievement as their low achievement will affect the school's ranking in the MOE league table for public examination outcomes.

\section{Background on Learning disabilities (LD)}

Learning Disabilities (LD) includes several sub-disorders which are sometimes referred to as academic skills disorders. Students with LD lag behind their typical peers in developing reading, writing or arithmetic skills. For example, dyslexia is a high-incidence disability (the most common diagnosis of developmental reading disability) affecting 3-5\% of school age children. Children with developmental speech and language disorders have problems to produce speech sound 
and using spoken language to communicate. Generally, the prevalence rate of LD range from $5-10 \%$ of school aged population (Culatta \& Tompkins, 1999). The causes of LD are numerous. Literatures point out a few that commonly cause LD such as hereditary, developmental retardation, prenatal damage, toxins, and injuries in early childhood (Turkington \& Harris, 2003).

Teachers have a right and a responsibility to be prepared for the task at hand. A more direct role of the mainstream education teacher in teaching students with special needs has demanded an increased understanding of the various types of disabilities plus types of appropriate curricular and instructional modifications. Another aspect that needs teachers' skills is interactions with disabled students in the classroom (Sabornie \& deBettencourt, 1997). Hence, it is vital for pre-service teachers to have an opportunity to learn about children with special educational needs in their training. As schools move to an inclusive model, in-service training should be provided for senior teachers who were without exposure in these areas.

Students with special educational needs (SEN), require a range of special support services in order to succeed in school. Typically, these services have been provided in specialized resource rooms or special education classes to meet individual needs of these students. In Malaysia, resource rooms make available service-delivery for students with visual impairments studying in mainstream classroom since more than four decades ago. On the other hand, special education classes were only designed for students with learning disabilities in 1988. Almost all students with LD were placed in special classes until the transformation of education. Nevertheless, inclusion of students with learning disabilities is more complex than it might appear to the general education system. Some students with learning disabilities in Malaysia possess average or above average intelligence, especially children with attention deficit hyperactivity disorder (ADHD) and Asperger's syndrome. There are barriers such as inadequate professional preparation, lack of information regarding students with special needs, and negative attitudes toward these students (Haniz, 1998; Pivic, McCombs, \& Laflamme, 2002) may affect the success of any inclusive education effort. Furthermore, efforts should be made to overcome the barriers that may influence regular education teachers' willingness to include students with special needs into their classes. 


\section{Teacher training}

Previous efforts towards inclusion in Malaysia have not been supported with serious efforts in restructuring the mainstream and special education links. Pre-service training programs for mainstream and special education teachers have remained separate with little or no linkages. As inclusive education is gradually implemented, resource room teachers or special education teachers have been assigned the sole responsibility of supporting students with special needs. Mainstream classroom teachers on the other hand, have not been involved in addressing the needs of the SEN students. According to Abdul Rahim, Rodger, and Ziviani (2012), Malaysian mainstream teachers' knowledge about children with LD was low and the special education teachers' knowledge about LD and SLD was also limited.

In the last few decades, research findings have suggested that for inclusive education to succeed, mainstream education teachers should be adequately prepared. More research in other countries has also been carried out on this topic for a long time. These findings have indicated that regular education teachers were not actively involved in addressing the needs of the students with SEN in mainstream classrooms (Ammer, 1984; Schultz, 1982). Similarly, little effort has been exerted in Malaysia to assess or enhance mainstream classroom teachers' knowledge of special educational needs. With the exception of a few studies addressing these teachers' attitudes towards inclusion (e.g., Haniz, 1998), no empirical studies have been conducted on regular classroom teachers' roles regarding inclusive education in Malaysia.

Children with LD are unique. In dealing with them, teachers are required to be knowledgable about the uniqueness of LD. The understanding of students' condition may help teachers to manage the teaching and learning (T\&L) appropriately according to the special needs of these children. A few research findings also show that teachers feel that pre-service and in-service education programs were inadequate in preparing them for teaching students with learning disabilities in mainstream classrooms (DeSimone \& Parmar, 2006; Wilson, Loprete, \& Slostad, 2000). Other research findings from different parts of the world have found that teachers' acceptance of inclusion may be promoted by educating them about the characteristics and behaviors of students with special needs (e.g., Carroll, 2003; Koay, Lim, Sim, \& Elkins, 2006; 
Lanier \& Lanier, 1996; Papadopoulou, Kokaridas, Papanikolaou, \& Patsiaouras, 2004; Trent, Pernell, Mungai, and Chimedza, 1998).

\section{Identification of $L D$}

Early identification of LD is important for schools in order to provide adequate program, therapist service and support. Treatment programmes such as special types of school-tasks, study skills training and social skills training are crucial for LD. Multidisciplinary evaluation teams are responsible in evaluating individuals with $\mathrm{LD}$. The members of the team include parents, teachers, clinical professionals and psychologists. Teachers are usually the first to notice students' persistent difficulties amongst the team members. Measurement of student's achievement is critical in the identification procedure for LD. In screening and diagnosis of LD, standardized tests are used to compare the child's level of abilities to what is considered normal for peers of that age (including intelligence).

\section{The Present Study}

The number of people with disabilities in Malaysia is substantial and it is likely to grow rapidly (MOE, 2010). It should be noted that the Malaysian educational system provides formal education (mostly in exclusive settings) to individuals with visible disabilities (e.g. visually impaired) and invisible disabilities (e.g learning disability). The study of learning disabilities is gradually gaining momentum as more and more students are experiencing problems in academic and non academic areas. Along with LD, ADHD is also found to be prevalent (Supiah, 2003). The diverse abilities and educational needs of children with LD require teachers to be knowledgeable. Nevertheless, Paul (2000) states that one of the barriers encountered by students with disabilities is teachers' lack of knowledge about the disability and the types of services and accommodations they require. Hence, assessing the knowledge level of learning disabilities among pre and in service teachers is of critical importance. As the success of inclusion of students with SEN partially depends on teachers' awareness of these students' needs (Campbell, Gilmore, \& Cuskelly, 2003; Papadopoulou, Kokaridas, Papanikolaou, \& Patsiaouras, 2004), this study was carried out to: i) investigate and gain understanding of mainstream teachers knowledge of learning disabilities and ii) gain insights on how teachers gain knowledge of learning disabilities. To achieve those objectives, the 
study sought to answer the following questions: 1) To what extent do Malaysia pre-service and in-service student teachers know the types and characteristics of students with learning disabilities? 2) Do Malaysian pre-service and in- service mainstream teachers' knowledge of learning disabilities differ according to age, gender, or teaching experience?

\section{Methodology}

The survey research method was used to investigate the research problem formulated in this study. The independent variables were represented by teachers' status, gender, age, and teaching experience. Teachers' level of knowledge of learning disabilities represented the dependent variables. As it's known however, survey research does not establish cause-effect relationships. Interviews with selected participants were carried out to validate the information collected.

\section{Population and sampling}

A purposefully selected sample of students from two public universities undergoing bachelor degree programs in education participated in this study. Pre-service student teachers are regular students in a public university majoring in several subjects in education. The main reason was that student teachers were expected to gain knowledge of LD while completing their training. These student teachers were in the third year of their training. On the other hand, in-service student teachers are those who were undergoing distant learning programmes. These students were in the first semester of their study, undertaking courses namely English as a second language, Islamic education or guidance and counseling as a major area in their study. It is expected that they gain some knowledge of LD from their experience while teaching mainstream students.

\section{Instrument}

An instrument developed by the researchers consisting of two parts was used to collect the research data. The first part contained four items related to demographic data. The second part was a 36 -item test measuring teachers' knowledge of learning disabilities. These items were formulated based on a review of relevant literature (Bender, 2003; Lerner, 1999; Mather \& Goldstein, 2001). Three subscale were used namely, type of disability, type of special education programme and the professional team in education of children with SEN. 
To establish the face validity of the test, an initial version of it was given to two lectures from University Pendidikan Sultan Idris (UPSI), from the Department of Special Education. They made comments then provided feedback on a few items and changes were made based on their suggestions. Also prior to distribution, the instrument was piloted on 50 in-service student teachers at IIUM and 50 pre-service student teachers at UPSI. Those student teachers were excluded from the study sample. Their responses provided useful feedback that was taken into account in the final version of the instrument. Reliability of this test was established using the test-retest (over two weeks) method. Pearson's Correlation Coefficient was (.873). The survey item was started with asking participants to write their name. Nonetheless, the participants were assured that the study was for scientific purposes only and that their responses were confidential and anonymous. They were urged to respond to all items to the best of their knowledge.

To determine the reliability coefficient of the scale, the researcher had conducted a pilot test. The Cronbach's alpha for each subscale are as follows: Subscale 1 - Type of disability (10 items); r= .890; Subscale 2 - Types of programme for children with SEN (6 items); $\mathrm{r}=.760$; Subscale 3 - Support, facilities and professional (6 items); $r$ $=.821$; Subscale 4 - Identification and policy/regulation regarding the education children with SEN (5 items); $r=.800$; Subscale 5 - Types of media used in gaining knowledge ( 9 items); $r=.852$. Thus, the items used to collect data for this study is reliable.

\section{Procedure}

Questionnaires were administered at IIUM and UPSI. Each copy was accompanied by a letter from the researcher explaining the intention of the study and the questionnaire, requesting student teachers' participation. In addition, a pen was also given as a token for their participation. To increase the student teachers' response rate, two follow-ups were made by the researcher and research assistant.

\section{Data Analysis}

SPSS statistical package was used in data analysis. To facilitate better understanding of statistic amongst variety background of readers, descriptive analysis which include a variety of statistical techniques were used to analyse the research data. These techniques included: 
frequencies, percentages, mean, standard deviation (SD). In addition to that, one-way analysis of variance (ANOVA) was utilised to show the significant of differences between and within groups.

Table 1

Distribution of Teachers According to status, gender, Age, teaching experience, and Academic Qualification

\begin{tabular}{|c|c|c|}
\hline Variable & Number & Percent \\
\hline \multirow{3}{*}{$\begin{array}{l}\text { Status } \\
\text { Pre-service } \\
\text { In-service }\end{array}$} & & \\
\hline & 149 & 50.3 \\
\hline & 147 & 49.7 \\
\hline \multirow{3}{*}{$\begin{array}{l}\text { Gender } \\
\text { Male } \\
\text { Female }\end{array}$} & & \\
\hline & 39 & 13.2 \\
\hline & 257 & 86.8 \\
\hline \multirow{6}{*}{$\begin{array}{l}\text { Age } \\
24 \text { Years or Less } \\
\text { 25-30 Years } \\
\text { 31-34 Years } \\
\text { 35-40 Years } \\
41 \text { Years and Above }\end{array}$} & & \\
\hline & 110 & 37.2 \\
\hline & 40 & 13.5 \\
\hline & 44 & 14.9 \\
\hline & 51 & 17.2 \\
\hline & 49 & 16.6 \\
\hline \multirow{4}{*}{$\begin{array}{l}\text { Years of Teaching } \\
\text { Experience } \\
6 \text { Years or Less } \\
7 \text { Years or More } \\
\text { Unspecified }\end{array}$} & & \\
\hline & 104 & 42.4 \\
\hline & 141 & 42.9 \\
\hline & 51 & 17.2 \\
\hline Total & 296 & 100 \\
\hline
\end{tabular}

Table 1 reports the distribution of respondents according to status (pre and in -service) gender, age, and years of teaching experience. Data in the Table also show that $50.2 \%$ of respondents were pre-service and $49.7 \%$ were in-service student teachers. In terms of 
gender, $13.2 \%$ were male and $86.8 \%$ were females. Regarding their age, $27.8 \%$ of the teachers were less than 25 years old (pre-service) and $13.5 \%$ were between 25 to 30 years old. The percentage of respondent older than 30 years old were as follows; $14.9 \%$ aged between $31-34$ years old; $17.2 \%$ aged between $35-40$ years old; and $16.6 \%$ were aged above 40 years old.

Regarding their teaching experience, $19.6 \%$ of respondents had no teaching experience (some of pre-service without experience). $42.4 \%$ had one to six years teaching experience. A total $42.2 \%$ had more than 7 years experience while $17.2 \%$ were unspecified about their experience.

\section{Findings}

\section{Types of Disability}

Under the subscale 1; types of disability, cognitive disability, were fairly well known (more than $70 \%$ ) by participants. In general, the percentage of teachers who claimed they are knowledgeable in different types of disabilities is presented in table 2 .

Table 2

Overall knowledge of student teachers regarding types of disability

\begin{tabular}{|l|l|}
\hline Type of disability & Percentage \\
\hline & \\
\hline Cognitive disability & 84.4 \\
\hline Physical disability & 81.0 \\
\hline Deaf & 78.7 \\
\hline Speech disability & 78.1 \\
\hline Blind & 77.6 \\
\hline Autism & 70.3 \\
\hline Dyslexia & 68.5 \\
\hline Multiple & 54.7 \\
\hline ADHD & 53.4 \\
\hline Cerebral Palsy & 37.5 \\
\hline
\end{tabular}


More than $80 \%$ of the respondents revealed that they knew about cognitive and physical disabilities. The visual impairment, hearing impairment, speech disability and autism were the other types of disabilities claimed to be known by more than $70 \%$ of the respondents. A total of $68.5 \%$ respondents revealed that they know about dyslexia. Multiple disabilities, ADHD and Cerebral Palsy were the type of disabilities less known by the student teachers that participated in this study; less than $55 \%$. Cross tabulation between independent variables and types of disability are presented in table 3, 4, 5 and 6.

\section{Table 3}

Knowledge of LD of student teachers based on gender, age, teaching experience and status (pre or in-service)

\begin{tabular}{|l|l|l|l|l|l|l|l|l|l|}
\hline & \multicolumn{2}{|l|}{ Gender } & \multicolumn{2}{l}{ Age } & \multicolumn{2}{l|}{ Experience } & \multicolumn{2}{l|}{ Status } \\
\hline $\begin{array}{l}\text { Types of } \\
\text { disability }\end{array}$ & Mean & SD & Mean & SD & Mean & SD & Mean & SD \\
\hline $\begin{array}{l}\text { Visual im- } \\
\text { pairment }\end{array}$ & 2.89 & .673 & 2.89 & .673 & 2.88 & .669 & 2.89 & .671 \\
\hline $\begin{array}{l}\text { Hearing } \\
\text { impair- } \\
\text { ment }\end{array}$ & 2.88 & .681 & 2.88 & .681 & 2.86 & .672 & 2.88 & .679 \\
\hline LD & 3.05 & .693 & 3.06 & .696 & 3.04 & .682 & 3.05 & .693 \\
\hline Physical & 3.01 & .714 & 3.02 & .714 & 2.98 & .710 & 3.01 & .714 \\
\hline Multiple & 2.58 & .718 & 2.51 & .714 & 2.59 & .691 & 2.58 & .718 \\
\hline Autism & 2.81 & .774 & 2.81 & .772 & 2.79 & .760 & 2.81 & .774 \\
\hline Dyslexia & 2.84 & .791 & 2.84 & .789 & 2.80 & .761 & 2.84 & .791 \\
\hline $\begin{array}{l}\text { Cerebral } \\
\text { palsy }\end{array}$ & 2.28 & .831 & 2.28 & .834 & 2.22 & .818 & 2.28 & .831 \\
\hline ADHD & 2.50 & .911 & 2.51 & .834 & 2.42 & .896 & 2.50 & .911 \\
\hline $\begin{array}{l}\text { Speech } \\
\text { problem }\end{array}$ & 2.92 & .678 & 2.92 & .678 & 2.90 & .684 & 2.92 & .678 \\
\hline & & & & & & & & \\
\hline
\end{tabular}


In terms of age, there were significant differences (at $p<.05)$ in all types of disability except for multiple disability. On the other hand, in terms of gender, there are significant differences in four types of disability namely visual impaired $\mathrm{F}(1,290)=6.61 ; \mathrm{p}=.011$; physical disability $\mathrm{F}(1,290)=4.35 ; \mathrm{p}=.038$; autism $\mathrm{F}(1,289)=7.01 ; \mathrm{p}=.009$; $\operatorname{ADHD} F(1,290)=12.36 ; \mathrm{p}=.001$.

Table 3

The sources and percentage of student teachers usage of sources in gaining knowledge about the types of disabilities

\begin{tabular}{|c|c|c|c|c|c|}
\hline Type of disability & Source & & & & \\
\hline & Media & $\begin{array}{l}\text { Short } \\
\text { course }\end{array}$ & $\begin{array}{l}\text { Special } \\
\text { course }\end{array}$ & Friends & $\begin{array}{l}\text { Neigh- } \\
\text { bors }\end{array}$ \\
\hline Visual impairment & 53.7 & 6.1 & 9.1 & 25.0 & 6.4 \\
\hline $\begin{array}{l}\text { Hearing impair- } \\
\text { ment }\end{array}$ & 51.7 & 7.4 & 8.1 & 27.0 & 7.1 \\
\hline $\begin{array}{l}\text { Cognitive disabil- } \\
\text { ity }\end{array}$ & 44.3 & 11.8 & 11.5 & 38.2 & 10.1 \\
\hline Speech disability & 47.3 & 7.1 & 8.4 & 28.7 & 7.4 \\
\hline Physical disability & 51.0 & 5.7 & 8.4 & 28.7 & 11.1 \\
\hline Multiple disability & 35.8 & 4.1 & 7.1 & 17.6 & 5.4 \\
\hline Autism & 44.6 & 14.5 & 11.1 & 22.0 & 4.4 \\
\hline dyslexia & 43.9 & 12.2 & 11.5 & 25.3 & 3.7 \\
\hline Cerebral palsy & 23.6 & 6.8 & 9.1 & 8.4 & 2.0 \\
\hline $\begin{array}{l}\text { Attention deficit } \\
\text { hyperactivity dis- } \\
\text { order (ADHD) }\end{array}$ & 32.1 & 9.8 & 11.5 & 15.9 & 2.4 \\
\hline
\end{tabular}

Out of five sources listed as a medium for respondents to get information, media was rated as the most popular /main source for respondents to know about all types of disabilities especially visual and hearing impairment and physical disabilities (more than 50\%). Friends were the other main source that provides knowledge about disabilities to the participants, particularly about cognitive disabilities $(38.2 \%)$, speech and also physical disabilities (28.7\%). Besides the media 
and friends, there were courses the participants attended regarding disabilities. Regarding the short and special course, $4.1 \%$ to $14.5 \%$ of respondents claimed that they had attended a short course and $7.1 \%$ to $11.5 \%$ claimed to gain knowledge through a special course that expose them to one type of disability listed in the instrument. It is obvious that media is the most popular way of information gained.

Table 4

Overall knowledge of student teachers regarding important facts related to educational provision for students with SEN

\begin{tabular}{|l|l|}
\hline Facts & Percentage \\
\hline Meaning of special education & 84.8 \\
\hline Program of special education in Malaysia & 82.8 \\
\hline Community based rehabilitation center (CBR) & 50.7 \\
\hline Homeschooling for children with SEN & 46.0 \\
\hline Integration programme & 40.3 \\
\hline Inclusive education for children with SEN & 5.7 \\
\hline
\end{tabular}

The instrument also included six items that focus on student teachers' knowledge about meaning and types of programmes for the education of children with SEN. The items and the percentage of responses are presented in Table 4 . More than $80 \%$ of respondents claimed that they know the meaning of special education terms and special education programmes allocated for children with disabilities. Half of them know about CBR, a programme for persons with disability (PWD) run by the Ministry of Women, Family and Community Development. More than $40 \%$ of them have knowledge about home schooling and integration programs for children with SEN. Unfortunately, only 5.7\% of student teachers in this study know about inclusive education. This results show that the implementation of inclusive education in Malaysia is at-risk of failure. Without enough exposure, mainstream teachers will be reluctant to accept the students with SEN in their classes. In term of gender, age and experience, there are no significant differences $($ at $p<.05)$ in all facts listed. However, there are significant differences in experience of student teachers in particular about the meaning of special education 
$\mathrm{F}(1,290)=10.53 ; \mathrm{p}=.001 ;$ special education programme $\mathrm{F}(1,290)=$ 9.95; $\mathrm{p}=.002$; and mainstreaming $\mathrm{F}(1,290)=25.71 ; \mathrm{p}=.000$.

In addition to the types of disabilities and the facts related to educational provision for students with SEN, 11 items related to other important facts regarding the education of students with SEN were also included in the instrument. The item and percentage of positive responses are presented in table 5 below. The data indicated that $80.1 \%$ of respondents in this study were aware about EFA policy. They were also aware about assistant teachers (75.7\%), special allowance for students with SEN (64.5\%), and screening process for children with SEN $(61.5 \%)$. More than half of the respondents know about professional involvements (56.8\%), EIP (55.1\%), and diagnosis procedures (52.7\%). However, participants were less aware about instruments used for screening, CRC, IEP, and multidisciplinary teams involved in the process of education of students with SEN.

Table5 Other important facts related to education for students with SEN

\begin{tabular}{|l|l|}
\hline Facts & Percentage \\
\hline EFA policy & 80.1 \\
\hline $\begin{array}{l}\text { Assistant teacher/ teacher } \\
\text { aides (PPM) }\end{array}$ & 75.7 \\
\hline $\begin{array}{l}\text { Allowance for students with } \\
\text { SEN }\end{array}$ & 64.5 \\
\hline Screening process & 61.5 \\
\hline Professional involvement & 56.8 \\
\hline $\begin{array}{l}\text { Early intervention programme } \\
\text { (EIP) }\end{array}$ & 55.1 \\
\hline Diagnosis procedure & 52.7 \\
\hline Instrument used for screening & 48.6 \\
\hline $\begin{array}{l}\text { Children Right Convention } \\
\text { (CRC) }\end{array}$ & 44.6 \\
\hline $\begin{array}{l}\text { Individual education plan } \\
\text { (IEP) }\end{array}$ & 41.2 \\
\hline Multidisciplinary team & 32.4 \\
\hline
\end{tabular}


There was an item asking whether respondents agreed that media is the most popular way to access information about learning disabilities. For those who agreed, they were required to choose nine types of media that they used. The results are as in table 6 below.

Table 6

Percentage of respondents and types of media used

\begin{tabular}{|l|l|l|l|}
\hline No & $\begin{array}{l}\text { Type of media used in gaining } \\
\text { knowledge about LD (listed in } \\
\text { the instrument) }\end{array}$ & $\begin{array}{l}\text { Number of } \\
\text { respondents }\end{array}$ & $\%$ \\
\hline 1 & Internet & 289 & 93.2 \\
\hline 2 & TV & 235 & 79.4 \\
\hline 3 & News paper & 233 & 78.7 \\
\hline 4 & Books & 220 & 74.3 \\
\hline 5 & Magazines & 213 & 72.0 \\
\hline 6 & MOE Portal & 169 & 57.1 \\
\hline 7 & Blog & 167 & 56.4 \\
\hline 8 & Face-book & 141 & 47.6 \\
\hline 9 & Radio & 116 & 39.2 \\
\hline 10 & $\begin{array}{l}\text { Others (need to be specified by } \\
\text { respondent) }\end{array}$ & none & None \\
\hline & & & \\
\hline
\end{tabular}

The most popular media used by respondents to access information about learning disabilities was internet followed by television and newspaper as well as books and magazines (respectively $93.2 \% ; 79.4 \% ; 78.7 \% ; 74.3 \% ; 72.0 \%$ ). A total of $57.1 \%$ used the Ministry of Education portal and 56.4\% used blogs to gain knowledge. Facebook and radio were the less popular way among the participants. In terms of direct interaction with persons with disabilities, $63.9 \%$ of respondents have a family member with disability, $40.2 \%$ gain handson experience with their students in classroom, $11.8 \%$ claimed that they have PWD neighbors, $8.8 \%$ has close PWD relative. 
One way analysis of variance (ANOVA) was used to determine if the apparent differences shown in the data were statistically significant. The results revealed that there were statistically significant differences in teachers' knowledge of learning disabilities attributed to status $\mathrm{F}(4$, $286)=3.006 ; \mathrm{p}=.019$ ) and there were no statistical differences in student teachers knowledge of LD were found according to student teachers' age $\mathrm{F}=(4,236)=2.155, \mathrm{p}=.075)$ and years of teaching experience $\mathrm{F}(4$, 278) $=.767, \mathrm{p}=.548)$.

\section{Discussion and Conclusions}

The teachers who participated in this study had an acceptable level of knowledge in learning disabilities. Since pre-service training programs for mainstream classroom teachers in Malaysia rarely include elements related to children with learning disabilities, their level of knowledge may be explained in terms of their reading or they may have gained knowledge about learning disabilities through television and radio or using the internet; interactions with special education teachers working in resource rooms in their schools (friend), courses attended, and communications/interactions with community members (neighbours). Also, there are occasional training workshops on children with special needs targeting parents and teachers as well as volunteers working with children with SEN. Most of the courses were run by NGOs. From the interview data, some of the student teachers who participated in this study had participated in such training. Previous studies have reported that such variables may influence teachers' acceptance and support of inclusion (Campbell et al., 2003; Papadopoulou et al., 2004; Wilson et al., 2000).

The findings of this study may be encouraging as they indicate that student teachers in Malaysia appear to have knowledge of learning disabilities. However, such knowledge does not necessarily mean that the teachers are able to provide for students with learning disabilities in their classrooms with the necessary adaptations and support services. Neither does that mean mainstream teachers may cooperate with resource room teachers. In light of this, future studies in Malaysia should address these issues. 
Schools in Malaysia are undergoing special education reform and inclusive education is one of the main thrust. The MOE is responsible to provide social justice and equality so that all students can be included in ways that enable them to achieve their full potential. As shown in table 4, the percentage of student teachers' knowledge on inclusive education is very small. This implies that they are not in the state of being 'ready' to participate effectively in teaching students with SEN. In 2015, most of the high functioning students with SEN will be placed in inclusive settings as intended by the MOE. Three years are needed for the MOE to prepare the mainstream teaching system for the task.

\section{Limitations}

There are limitations which may influence the generalization of findings in this study. The sample used as not a random sample but a purposefully selected one. Thus, the findings of this study are not a representative of the larger population of mainstream student teachers. Also, the sample represented a small segment of the student teachers selected from two public universities in Malaysia and that the sample may differ from the student teacher population of other universities in the country. Another limitation of the present study was the test used to assess teachers' knowledge of learning disabilities. This test was not a comprehensive one in that it did not cover all basic domains related to learning disabilities. Several thousand students with learning disabilities are expected to be in mainstream schools where there is no provision of special education services and where teachers have not been informed of learning disabilities in pre-service or in-service training. Thus, future studies addressing teachers working in such schools are obviously needed. Finally, future research needs to use more comprehensive tests and interviews with student teachers to verify this study's findings.

\section{Future Research}

This small scale research provides insights related to the knowledge of student teachers in learning disabilities. As the number of students with LD increase drastically every year, and the MOE is very keen in implementing an inclusive education, there is a need for more short courses and special courses in special educations field, specifically designed to cater for staff development of mainstream teachers. With this regard, IIUM should take the opportunity to contribute in providing 
short courses to the public especially mainstream teachers. The knowledge gain through the course together with Islamic values that they have, the problems and barriers related to teaching and learning of students with SEN in mainstream classes can be reduced. The center for teaching learning (CTL) of Kulliyyah of education (KOED) is the suitable platform to run these short courses.

\section{References}

Ammer, J. (1984). The mechanics of mainstreaming: Considering the regular educators' perspective. Remedial and Special Education, 5 (6), 15-20.

Bender, W. (2003). Learning disabilities: Characteristics, identification, and teaching strategies. Allyn \& Bacon.

Campbell, J., Gilmore, L., \& Cuskelly, M. (2003). Changing student teachers' attitudes towards disability and inclusion. Journal of Intellectual \& Developmental Disability, 28(4), 369-379.

Carroll, A. (2003). The impact of teacher training in special education on the attitudes of Australian preservice general educators towards people with disabilities. Teacher Education Quarterly, 30(3), 65-79.

Culatta, R.A., Tompkins, J.R., (1999). Fundamentals of Special education: What every teacher needs to know. Upper saddle River, NJ: Prentice Hall..

DeSimone, J., \& Parmar, R. (2006). Middle school mathematics teachers' beliefs about inclusion of students with learning disabilities. Learning Disabilities Research \& Practice, 21, 98-110.

Gallagher, D.J. (Ed.). Challenging orthodoxy in special education: On longstanding debates and philosophical devides. In L. Florian (Ed.), The Sage Handbook of special education (pp. 515-527). London: Sage publications.

Hallahan, D., \& Kauffman, J. (2000). Exceptional learners: Introduction to special education. Boston: Allyn \& Bacon.

Koay, T., Lim, L., Sim, W., \& Elkins, J. (2006). Learning assistance and regular teachers' perceptions of inclusive education in Brunei Darussalam. International Journal of Special Education, 21(1), 119-130.

Lanier, N., \& Lanier, W. (1996). The effects of experience on teachers' attitudes toward incorporating special students into the regular classroom. Education, 117, 234-241.

Lerner, J. (1999). Learning disabilities: Theories, diagnosis, and teaching strategies (8th ed). Houghton Mifflin Company. 
Lokerson, J. (1992). Learning disabilities. ERIC Digests (ED352779).

Mather, N., \& Goldstein, S. (2001). Learning disabilities and challenging behaviors: A guide to intervention and classroom management. Paul $\mathrm{H}$. Brookes.

Mercer, C. (1997). Students with learning disabilities (5th ed). Upper Saddle River, NJ: Prentice Hall/Merrill.

Papadopoulou, D., Kokaridas, D., Papanikolaou, Z., \& Patsiaouras, A. (2004). Attitudes of Greek physical education teachers toward inclusion of students with disabilities. International Journal of Special Education, 19(2), 104-11

Pivic, J., McCombs, J., \& Laflamme, L. (2002). Barriers and facilitators to inclusive education. Exceptional Children, 69(1), 97-107.

Schultz, L.R. (1982). Educating the special needs student in the regular classroom. Exceptional Children, 48 (4), 366-68.

Wilson, K., Loprete, S., \& Slostad, F (2000). Classroom teachers' perceptions about inclusion and preservice teacher education. Teaching Education, 11 (2), 147-158.

Thomas, G., \& Loxley, A.(2001). Deconstructing special education and constructing inclusion. Buckingham, England: Open University Press. 